\title{
Fra barnløshed til forældreskab
}

Af Tine TJørnhøJ-Thomsen

At blive foraldre ved hjalp af medicinsk teknologi og ekspertise er en belastende proces, der gor tilblivelsen anderledes og satter sig spor $i$ den efterfolgende graviditet.

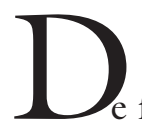

fleste mænd

og kvinder tager for givet, at de kan blive forældre, når de ønsker det og beslutter sig for det. Men det er ikke altid, kroppene formår dette projekt, og flere og flere par søger derfor medicinsk behandling for at forsøge at få det ønskede barn. At blive forxldre bliver derved en langt mere kompliceret og belastende proces, end de havde forestillet sig. Formålet med denne artikel er at belyse, hvad der er på spil for de mænd og kvinder, der ikke kan få børn ved egen hjælp, hvorfor de vælger at gå i medicinsk behandling for barnløshed, og hvad mødet med forplantningsteknologien ${ }^{1}$ samt klinikkens rum og eksperter indebærer for deres liv og den efterfølgende graviditet.

Den overordnede analytiske ramme for denne belysning er begrebet tilblivelseshistorier. Tilblivelseshistorier er kulturspecifikke narrativer om, hvordan individer bliver til, hvem eller hvad der er aktører og bidragsydere. De skildrer, hvorledes de involverede parter er forbundet og betydningen af den- 
ne forbundethed mere generelt, ligesom de fortæller om reproduktionens rette kontekst og vilkår (Delaney 1991). Tilblivelseshistorier er således det unikke svar, forældre giver deres børn, når de spørger om deres tilblivelse, men historierne er samtidig også spundet ind i og refererer til mere omfattende, dominerende, kollektive fortællinger om verdens orden og menneskers placering i den.

Min hensigt er at vise, hvorledes den almindelige tilblivelseshistorie og den orden, den konstituerer, anfægtes og ændres i forbindelse med infertilitet og mødet med medicinsk teknologi, og hvorledes dette både ekspliciterer og destabiliserer forestillinger om køn, slægtskab, forbundethed og autenticitet. De barnløse, der får børn efter medicinsk behandling, skal under alle omstændigheder gennemleve og fortælle en anderledes tilblivelseshistorie, og hvad det indebærer mere specifikt, diskuterer jeg til slut i min artikel.

Artiklen er baseret på en empirisk undersøgelse af ufrivillig barnløshed og forplantningsteknologi i Danmark (TjørnhøjThomsen 1999a, b). Det empiriske fokus i denne undersøgelse er de barnløse mænds og kvinders overvejelser og erfaringer forbundet med at være infertile og ufrivilligt barnløse og med at gennemgå forskellige former for fertilitetsbehandling. ${ }^{2}$

\section{TILBLIVELSESHISTORIER}

De fleste børn spørger på et tidspunkt, hvordan de er blevet til, hvor de kommer fra - eller hvor de var før. Forældre kan hente hjelp til svaret i børnebøger med titler som: "Hvor kommer jeg fra?" eller "Den nat Kristian blev til". Lad mig indledningsvis give et par eksempler på, hvad forældre i Danmark læser for deres børn:

"Mortens sædceller og Helles æg går nu i gang med at bygge et barn, der er en blanding af Morten og Helle. Ægget glider ned og sætter sig fast på væggen i livmoderen, og her begynder det at vokse. Først er der næsten ingenting. Så bliver det til noget, der nærmest ligner en fisk. Men efter nogle måneder kan man godt se, at det skal blive til et barn.” (Kaaberbøl og Dyhre-Poulsen 1993)

“Næsten alle dyr laver også børn på den måde. De står som regel op. Men dyr boller kun for at få unger. Mennesker gør det mest, fordi de synes, det er dejligt at være sammen med en, man elsker på den måde.” (Bech-Jessen 1987)

At læse disse bøger som mor er at læse dem fra et "indfødt" perspektiv, hvor de fremstår som velkendte, sande og universelle. Som antropolog læser man bøgerne med en bevidsthed om relativiteten i verden og om kulturelle og sociale forskelle i verdenssyn og rationalitet (Hastrup 1992). Fra dette perspektiv træder børnebøgerne frem som interessante etnografika om en specifik, lokal livsverden.

\section{FORTÆLLINGER OG ORDEN}

Ideen til at inddrage børnebøger som en lille del af mit etnografiske materiale stammer fra antropologen Mary Bouquet (1993), der analyserer Beatrix Potters Peter Rabbit-bøger som en mini-etnografi om engelsk slægtskab. Bouquet påpeger, at børn lærer om socialt virksomme kategorier og verdens orden fra de bøger, deres forældre læser for dem (Bouquet 1993, 195). En tilsvarende pointe findes hos antropologerne Sylvia Yanagisako og Carol Delaney (1995, 1-2), som peger på den betydning, oprindelsesmyter har for personers og folkeslags identitetsforankring og for deres forestilling om fremtiden. Oprindelsesmyter, som også omfatter religiøse og naturvidenskabelige oprindelsesmyter i vores del af verden, fortæller mennesker om, hvad verden består af, dens indretning og orden, og hvordan de er placeret i denne orden (Yanagisako og Delaney 1995, 1-2). Der er, 
understreges det, en nær forbindelse mellem oprindelsesmyter og tilblivelseshistorier: "Stories of origin have to do with notions of "coming-into-being", simultaneously physiological, social and ontological" (Yanagisako og Delaney 1995, 3). Oprindelsesmyter og tilblivelseshistorier har således betydning for samfunds selvforståelse og sociale organisation, samt for menneskers identitet, forståelser af omverdenen og deres hverdagspraksisser. Tilblivelseshistorier og oprindelsesmyter er ikke statiske størrelser, de ændrer sig i forhold til nye former for viden og nye kontekster, hvilket ikke anfægter deres ordens- og meningsskabende egenskaber. Der kan dog opstå situationer, hvor en dominerende fortælling ikke mere giver mening, og hvor den kosmologi og verdensorden, den er med til at konstituere, destabiliseres. Det kan betyde, at personer og grupper oplever identitetsmæssig desorientering og usikkerhed om fremtiden (Yanagisako og Delaney 1995, 2) og må arbejde på at genskabe orden og kontinuitet.

Den viden, børnebøgerne formidler, gælder for eksempel ikke de ufrivilligt barnløse. De skal fortælle - eller fortie - anderledes fortællinger (Tjørnhøj-Thomsen 1999a). De anderledes tilblivelseshistorier destabiliserer kendte ordener og etablerer nye, og implikationerne heraf skal jeg vende tilbage til. Men før det er det relevant at spørge, hvad det er, børnebøgerne fortæller om socialt virksomme kategorier og verdens orden, og hvordan de knyttes sammen med forestillinger og praksisser vedrørende slægtskab og køn.

\section{FORTÆLLINGER FOR BØRN}

Alle de børnebøger, der indgår i mit materiale, indleder med at lære børn om en grundlæggende orden: Forskellen mellem kønnene. Forskellen mellem mænd og kvinder konstrueres med henvisning til kønsorganernes og kroppenes forskellige funktioner i forplantningsprocessen. Først beskrives de synlige og ydre forskelle, hvorefter den illustrerede fortælling bevæger sig ind $\mathrm{i}$ de kønnede kroppe og med billeder, grafik og tværsnit beskriver de indre. Her præsenteres læseren også for kønscellernes forskellige oprindelse, morfologi og bevægelsesmønstre.

Viden om kønsforskelle er afgørende for at forstå den seksuelle akt, som er en af fortællingens nøglebegivenheder. Heteroseksuel kærlighed og lyst (kæleri og intimitet) er en forudsætning for at sætte børn i verden. Nogle bøger lægger også vægt på, at barnet er et produkt af forældrenes fælles ønske og deres ansvarlige livsplanlægning, det er altså vigtigt at være onsket og timet. Herefter flytter den illustrerede fortælling sig ind i de nu forenede kroppe, hvor vi følger kønscellernes ruter, møde, sammensmeltning og graviditetens faser. De fleste børnebogsfortællinger er således bygget op omkring et "standard befrugtningsnarrativ" (Franklin 1992, 77), hvor forplantningens kendsgerninger følger et nøje tidssammenhængende forløb af nødvendigt forbundne biologiske hændelser: Sex, kønscellernes lange vandring mod forening, befrugtning, graviditetens mange stadier og endelig den lykkelige fødsel.

Flere af børnebøgerne gør brug af et særligt kønnet billedsprog, en metaforik, som også genfindes i medicinske fremstillinger. Et manifest eksempel er portrætteringen af sædcellerne og deres rolle $\mathrm{i}$ befrugtningen. Sædcellerne er ofte "personificerede" eller "animerede" som små mænd, haletudser eller "sædbasser". De er hurtige, de er mange, og de konkurrerer, for det gælder om at komme først. Ægget er blot sig selv, anonymt, langsomt og passivt. Sprog og metaforer spiller en væsentlig rolle for viden, forventninger til og praksisser forbundet med kroppen og det reproduktive liv (jf. Martin 1991).

Børnebøgerne præsenterer også en anden orden, der vedrører nogle centrale aspekter af forældreskab og slægtskab. Det fortælles for eksempel, at "de to, der har la- 


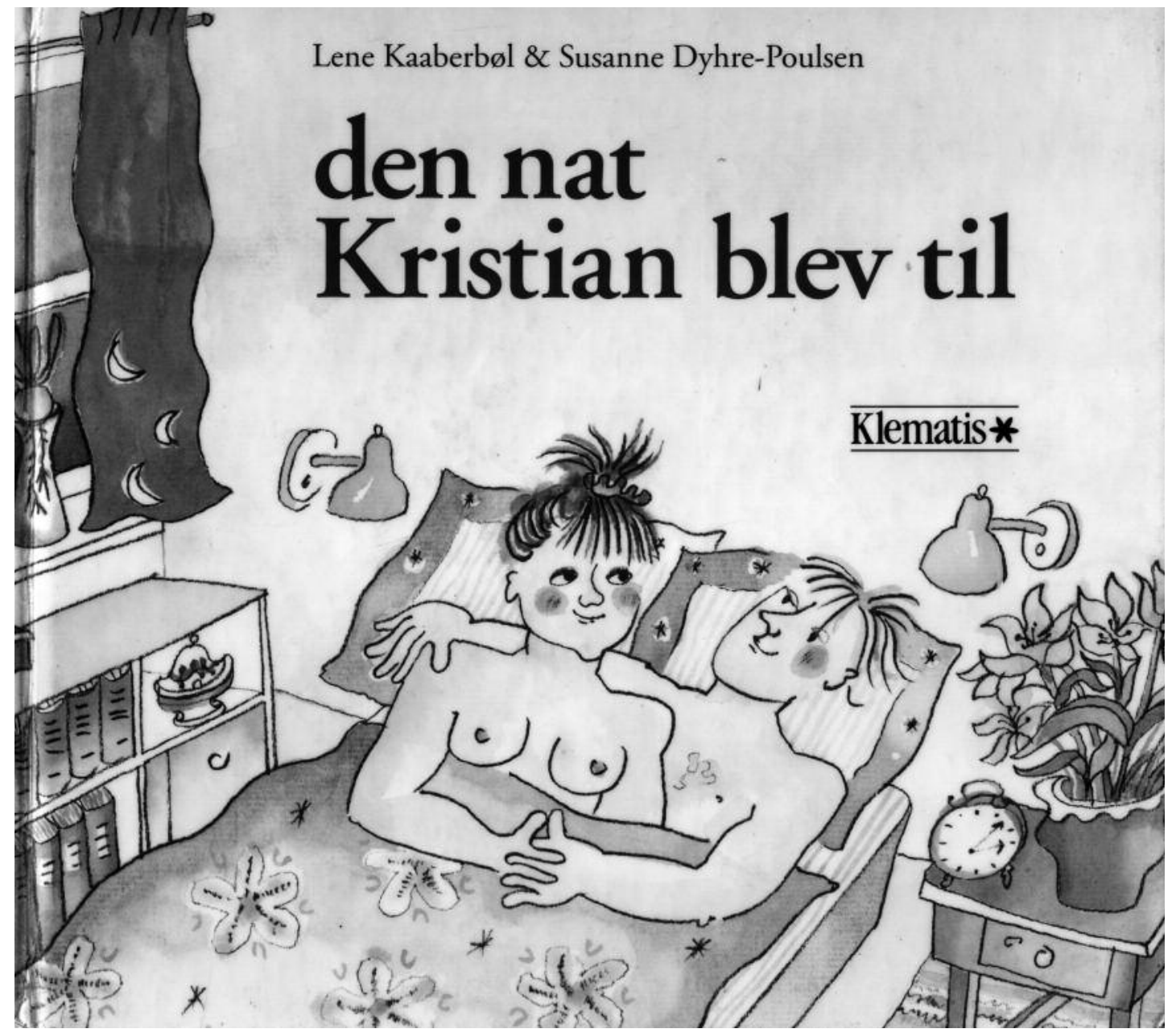

Forside på Lene Kaberbol og Susanne Dybre-Poulsen (1993):

Den nat Kristian blev til. Klematis Forlag. 
vet dig er din far og mor" (Mayle 1975), og at barnet er et produkt af deres "halve" genetiske bidrag, som også afgør, hvem barnet ligner. Barnet bliver altså til en hel ved at modtage halvt fra hver af forældrene og konstrueres som en person allerede ved befrugtningen. Graviditeten er primært karakteriseret som vækst- og ventetid. De danske børnebøger betoner således, hvad der generelt gælder for en vesteuropæisk forståelse af slægtskab, nemlig at de, der bidrager genetisk og kropsligt også er dem, der inden for familielivets særlige rammer drager omsorg for børnene (jf. Strathern 1995). I børnebøgerne er det biologiske forældreskab sammenfaldende med det sociale. Bøgerne eksponerer også den kulturelle betydning af at få eget, genetisk beslægtet barn og betydningen af den genetiske forbundethed for arv, udseende, oprindelse og identitet.

En væsentlig pointe er, at fortællingerne ikke kun handler om, hvordan børn bliver til, men også om hvordan kvinder bliver mødre, mænd fædre; hvordan forældre, familie og generationer bliver til. I mere generelle termer handler de om, hvordan specifikke identiteter og særlige former for sociale relationer skabes kulturelt. Det, der gør slægtskabs- og familierelationer særegne i vores samfund, er netop forestillingen om slægtskabsrelationernes tilblivelse i den biologiske og kropslige forplantningsproces. Den heteroseksuelle og biologiske forplantnings dominerende symbolske status i vesteuropæisk slægtskab og identitet har imidlertid ikke universel gyldighed. I nogle samfund bliver personer slægtninge ved over tid at dele den mad, der er lavet omkring samme ildsted (Carsten 1997). I andre samfund er fortællingen, at kvinder bliver gravide ved, at en forfædreånd tager plads i kvindens krop, mens mandens rolle kan være at nære den med sin sæd (Strathern 1992a).

Vi kan i børnebogscitaterne ovenfor spore elementer fra Darwins fortælling om arternes oprindelse og om vort nære slægt- skab med dyrene. Den vestlige biomedicin og ikke mindst et af dens vigtige erkendelsesredskaber, visualiseringsteknologien, hvormed eksperter ser ind i kroppe og forstørrer kropssubstanser, gennemtrænger også fortællingerne for børn. Børnene lærer om fælles menneskelig oprindelse og identitet, for eksempel at vi alle har været "prikker" og er "blevet til på den samme måde" (Fagerström og Hansson 1993). Men dette er ikke tilfældet, som vi skal se.

Fxlles for børnebøgernes selvforståelse er, at børnene med usvigelig sikkerhed vil spørge, og at forældrene er moralsk forpligtede på fortællingen, altså den sande historie "uden dikkedarer" (Mayle 1975). Tilblivelseshistorier lader sig altså ikke uproblematisk fortie, de fordrer at blive fortalt. Både blandt mine barneløse informanter og i et større offentligt rum er der enighed om, at børn bør vide, hvor de kommer fra, fordi det er vigtig for deres identitet og selvfølelse. Spørgsmålet, der melder sig, er, hvilke implikationer det har, når denne fortælling ikke folder sig ud som ventet, og når forplantningsteknologien bliver en del af tilblivelsen og fortællingen om den?

\section{ANDRE MÅDER AT FÅ BØRN PÅ}

Infertilitet udløser en uorden i menneskers kroppe og liv. Tilstanden udløser først en følelse af at være blevet snydt af kroppen. Den kropslige uformåenhed anfæxter kønsidentiteten og følelsen af at være en "rigtig" mand eller kvinde. Men infertiliteten truer også forventningen om et liv med børn og en særlig kulturelt informeret livsprogression. Mange føler, at de ikke kan komme videre i deres liv, de føler sig usikre på fremtiden og på parforholdets bestandighed, og situationen genererer identitetsmæssig desorientering (Tjørnhøj-Thomsen 1999a). De kan opleve, at de sakker agterud i forhold til det frellesskab, de har haft med jævnaldrende venner, og netop følelsen af at være udelukket af de mange fællesskaber og ritualer, som reproduktive erfa- 
ringer og børn giver adgang til, er med til at forstærke følelsen af ikke at høre til eller være kompetent. De barnløses ideer om at være "rigtig" handler også om at få "egne" genetiske børn og dermed reproducere personlig identitet (Tjørnhøj-Thomsen 1999a, 102-103). Den genetiske forbundethed symboliserer tillige en stabil, emotionelt sikker forbindelse.

Når ufrivilligt barnløse par ${ }^{3}$ vælger at gå i behandling for barnløshed, forsøger de sig ofte med nogle enkle metoder som insemination og hormonbehandlinger først og bliver, hvis de ikke lykkes, henvist til teknisk og fysisk mere krævende metoder som reagensglasbefrugtning (IVF) og mikroinsemination (ICSI). Det er, når disse metoder ikke lykkes efter gentagne forsøg, eller hvis behandlingen bliver for belastende for kvinden og for parforholdet, at brug af sæddonor ${ }^{4}$ eller adoption overvejes.

Parret må altså, som noget uvant, forhandle indbyrdes om måden at få børn på. Forhandlingerne kan dreje sig om, hvor mange behandlingsforsøg kvinden skal gå igennem, for at manden kan blive far til sit eget barn, og for at de sammen kan få deres fælles, eget barn. De kan dreje sig om, hvorvidt mandens præference for adoption og uvilje mod brug af sæddonor skal hindre kvinden $\mathrm{i}$ at opleve graviditet, fødsel og amning, som er erfaringer og kompetencer, mange barnløse kvinder længes efter. Beslutningen om at få et barn bliver derved en kompliceret proces, hvor meget forskellige hensyn til helbred, parforhold, identitet og slægtskab skal forhandles.

For mange par er fravalget af det genetiske forældreskab en svær proces. Både den kulturelle betydning af at være genetisk forbundet og andre aspekter af slægtskab bliver særlig tydelige i overvejelser vedrørende sæddonation og adoption. I vores samfund er det umuligt ikke at tænke en genetisk forbindelse som slægtskab (jf. Strathern 1995) og dermed som en relation, der kalder på særlige forpligtelser og følelser. For de infertile mænd, der er nødt til at overveje donor, er det for eksempel svært ikke at tænke sæddonoren som en slægtning eller far til barnet og dermed også som en potentiel trussel mod mandens relationer til partneren og til barnet. Udsigten til ikke at være genetisk forbundet med barnet skaber ind i mellem tvivl om den emotionelle forbundethed til barnet og om relationens bæredygtighed og bestandighed.

For nogle par fører overvejelser om brug af sæddonor til tanker om, hvorvidt deres forskellige forbundethed til barnet vil bringe en ubalance ind i relationerne, ikke kun i forhold til barnet, men også i deres indbyrdes forhold. Ideen om ubalance bliver forståelig, hvis den relateres til den dominerende forestilling om, at barnet får "halvt fra hver" af sine forældre, som det står i børnebøgerne, samt til forestillingen om, at den genetiske forbindelse bærer særlige følelser, forpligtelser og stabilitet med sig. Ideen om ubalance associerer også til ideer om, at parternes indbyrdes forhold styrkes og stabiliseres ved, at de får et fælles barn (Tjørnhøj-Thomsen 1999a, 152-53), og til betydningen af lighed, symmetri og fælleshed i parforholdet. Tanker om ubalance får nogle til at foretrække adoption, hvor de potentielle forældre forestilles at være "lige" - men altså ikke genetisk - forbundet til barnet. For andre afgøres beslutningen om brug af donor ud fra et hensyn til kvinden (hvis krop og hverdagsliv i særlig grad belastes af de hormonbehandlinger og hyppige interventioner, der er forbundet med fertilitetsbehandling) eller af hendes ønske om at opleve graviditet, fødsel og amning. Nogle lægger vægt på, at både den potentielle far og mor kan følge graviditeten fra begyndelsen og dermed kontrollere, hvad barnet udsættes for under graviditeten. Som en kvinde sagde: "Altså, hvis jeg har et barn i maven, vil jeg gøre mit bedste. Hvis jeg adopterer et barn, så ved jeg ikke, om det er en alkoholiker eller narkoman, eller om der er tale om fejlernæring. Det er, hvad jeg ser er et plus ved donor. At jeg 
ved, at det barn, der kommer ud, er båret mest muligt korrekt."

De, der ikke kan få deres eget (fælles) barn, må under alle omstændigheder igennem en mere omfattende redefinitionsproces, hvor de bestræber sig på at nedtone og omdefinere den kulturelle betydning af genetisk forbundethed og biologisk forældreskab. De skal genskabe en anden orden. De fleste benytter en strategi, hvor de betoner de sociale aspekter af forældreskabet: Familielivet, nærhed og det at præge børnene bliver det væsentligste. I den proces forestilles varig og stabil forbundethed ikke som givet qua den biologiske forplantning, men qua menneskelig nærhed og interaktion over tid. I samme proces gives begreber som "rigtig", "biologisk" og "ligne" nye betydninger (Tjørnhøj-Thomsen 1999 a,b). Vanskeligst er omskrivningsarbejdet for dem, der efter mange års ufrivillig barnløshed og fertilitetsbehandling ikke får børn overhovedet. De må finde andre måder at udfolde forældreskabets og slægtskabets kvaliteter på.

De anderledes tilblivelser bringer spørgsmålet om, hvad man skal fortælle barnet, $\mathrm{i}$ forgrunden.

Mange af de potentielle forældre i min undersøgelse gør sig tanker om, hvordan og hvornår de skal fortælle barnet om dets tilblivelse. De fleste ønsker ikke at holde barnets tilblivelse hemmelig, fordi viden om oprindelse og tilblivelse betragtes som en vigtig viden at give barnet. Men det er samtidig svært at vide, hvad man skal fortælle, hvornår og hvad en anderledes fortælling vil betyde for relationen til barnet og for barnets selvfølelse og identitet.

\section{SVÆRE FRAVALG}

Reproduktionsteknologien skaber visioner om valgfrihed og kontrol, skriver antropologen Marilyn Strathern (1992b). Hun diskuterer implikationerne af de nye valgmu- ligheder, teknologien befordrer, for blandt andet forståelser af slægtskab og individualitet og for forholdet mellem samfund og natur. At burde vælge og at handle gennem valg er karakteristisk for det, Strathern kalder "Enterprise Culture". I "Enterprise Culture" implementeres valget gennem konsumption, og ved at vælge manifesterer subjektet sin individualitet (Strathern 1992b, 36). For dette “enterprising self” er der ifølge Strathern "no choice not to comsume...no choice not to make a choice" (Strathern 1992b, 37, original kursiv). "Enterprising culture" trænger sig også på i de barnløses møde med den medicinske teknologi. Fravalget af børn er i sig selv et vanskeligt valg, og det gælder også fravalget af behandlingen og teknologien. Dette kommer til udtryk i udsagn som: " Det hele ville være lettere, hvis teknologien ikke var der." Nogle føler, at de er "hoppet på en vogn", de ikke kan stige af. Samtidig ønsker mange at have "gjort, hvad de kunne" for at få et barn (Tjørnhøj-Thomsen 1999a). Men når det gælder fertilitetsbehandling, er det langtfra klart, hvornår man har gjort, hvad man kan, for der er ikke altid nogen åbenlys grund til ikke at forsøge igen, hvis et behandlingsforsøg mislykkes. Det beror blandt andet på, at der sjældent kan gives nogen entydig forklaring på, hvorfor behandlingen ikke lykkedes, når alt så "perfekt" ud. Fravalget bliver svært, når der er brugt megen livstid, energi og økonomiske ressourcer på at få et barn.

\section{KLINIKKENS RUM}

"Altså, hvis man skal se på vores situation som helhed, så synes jeg, det er blevet enormt kedeligt. Altså det der med spændingen vedrørende at fă børn. Normalt er det jo noget, der foregår i et soveværelse med lyset slukket - eller tændt. Men det er kun dig, din mand eller partner, der er involveret i det her. Nu er alle involveret i det her, og det gør det enormt aseksuelt på en eller anden måde. Der er ikke nogen spænding i det, der er ikke no- 
get interessant eller mystisk ved det, hvis der er det omkring det at få børn. Det er ikke noget med, at Lone tager en graviditetsprøve en dag, jeg er ved bageren, og siger: "Tillykke far" eller et eller andet. Næ, klokken 12 skal vi have sat $x g$ op, og klokken 14 nogle dage efter kan vi fă at vide, om der er sket noget. Det hele er planlagt efter en kalender, og det gør det lidt tamt."

Denne lille beretning fortalt af en infertil mand (Tjørnhøj-Thomsen 1999a, 172) giver et godt indtryk af, hvordan tilblivelsen bliver anderledes, når medicinsk teknologi bliver en del af den. At manden taler om, at " $i$ " skal have "sat xg op" er muligvis en fortalelse. Men som de fleste mænd i min undersøgelse forsøger han at leve op til forventninger om, at mænd og kvinder er "fælles" om reproduktive anliggender, hvilket også indebærer mænds tilstedeværelse og nærvær i det reproduktive rum. "Vi"-et kommer imidlertid også til at skjule den kendsgerning, at det er kvindens krop, der er i centrum, uanset om barnløsheden beror på mandens eller kvindens infertilitet. Mændene føler sig derfor ofte sat på sidelinien i klinikkens rum. De har svært ved at finde ud af, hvor de skal stå, hvordan de skal agere, hvordan de skal støtte deres partner, og de kan føle sig skyldige og ubehjælpsomme. På nogle klinikker søger man at inddrage mændene ved at give dem fjernbetjeningen til den skærm, på hvilken parret kan følge - og manden kan zappe mellem - ultralydsbillederne af xgudtagningen og laborantens mikroskop-frembragte billeder af de udtagne $\mathfrak{x g}$.

I det følgende vil jeg begrebsliggøre, hvordan tilblivelseshistorien bliver anderledes i klinikkens rum ved at referere til tre forbundne processer karakteriseret ved begreberne fragmentering (opsplitning) transgression (grænseoverskridelse og grænseforskydning) og disciplinering.

På den ene side fragmenterer forplantningsteknologien kulturspecifikke domæner (relationer, totaliteter) mennesker alminde- ligvis insisterer på at holdes sammen på. På den anden side, og samtidig, overskrider og forskyder teknologien grænser mellem og forbinder på nye måder domæner, vi almindeligvis insisterer på at holde adskilt. Endelig bevirker teknologiske praksisser forskellige former for disciplinering og objektivering, kontrol og overvågning af menneskers kroppe og liv.

\section{Fragmenteringer}

Helt overordnet adskilles sex og reproduktion på en ny måde. I klinikkens rum er sex ikke en forudsætning for reproduktion. Ved at adskille reproduktive substanser og kønsceller fra deres kropslige oprindelse kan de både opbevares og afhændes. Når befrugtningen udskilles fra kroppen, skabes en helt ny bevidsthed om reproduktive substanser og befrugtede $x g$, hvilket også nødvendiggør beslutninger om disse nye enheders status. For eksempel hvor længe de må opbevares, om rettighederne til dem om de må doneres eller sælges.

Hvad der er forenet (kærlighed, sex, samleje, befrugtning) i den almindelige tilblivelseshistories standardnarrativ, splittes op og forskydes i tid og rum. Forplantningsprocessen deles op i forskellige mindre trin: Hormonbehandlinger, sædafgivning, xgudtagning, befrugtning, xgoplægning, der er nøje skemalagt og varetages af forskellige specialister i specifikke og afgrænsede rum. Klinikkens rumlige indretning (med nøje adskilte rum til for eksempel kønsceller, patienter og klinikpersonale) afspejler således også tilblivelseshistoriens fragmentering.

Et andet aspekt af fragmenteringen beror på den intense fokusering på og objektivering af den fysiske krop, som uddyber splittelsen mellem kroppen og selvet og mellem det fysiske og det følelsesmæssige. Kvinderne talte ofte om at være adskilt fra og betragtere til deres egne kroppe. "De tænker kun på min krop - ikke på mig," som en kvinde udtrykte dette mere generelle forhold, at den medicinske fokusering på krop- 
pen afstedkommer usynliggørelse af de psykologiske og emotionelle aspekter af at gå i behandling. At denne splittelse mellem krop og selv sætter sig længerevarende spor, kunne jeg konstatere, da en kvinde længe efter at have forladt fertilitetsbehandlingen fortalte, hvordan hun stadig prøvede at "generobre kroppen" og, som hun sagde, genvinde sit seksualliv. Et element i hendes private helingsstrategi var at gå til mavedans.

\section{Granseforskydninger}

Den medicinske teknologis granseoverskridende eller grænseforskydende effekt manifesterer sig på flere niveauer. Fertilitetsbehandlingen rykker for eksempel ved de almindelige grænsesætninger mellem det private og det offentlige. Tilblivelsen flyttes ud i det offentlige rum. Den kommer til at involvere langt flere aktører end den intime, erotiske tosomhed, som den almindelige tilblivelseshistorie foreskriver - med tab af privatliv og kontrol, sårbarhed og følelser af akavethed til følge (jf. Cussins 1998). 5 Parret bliver afhængig af medicinske og tekniske eksperters know how, og deres mulighed for at få et barn bliver et offentligt, politisk og etisk anliggende (Franklin 1995). "Nu er alle pludselig involveret i det her," som det blev sagt i citatet, der indledte dette afsnit.

Teknologien overskrider også grænser mellem det synlige og det usynlige.

Det er blikket ind i kroppen via blandt andet ultralydsskanninger, der afgør, om behandlingen virker, ligesom det er blikket på kønscellerne, der afgør, om de er tilstrækkelige og modne. Ved at se, hvad læger og laboranter ser, indvies de ufrivilligt barnløse $i$ et specielt biomedicinsk vidensog vurderingsgrundlag, der introducerer nye og uvante måder at erfare og fortælle om kroppen - og dermed også om selvet på (jf. Sandelowski 1994). Mange barnløse kvinder fortalte således om deres "mange follikler" eller deres "flotte" xg med stolthed og håb. Det, at kroppen reagerer hen- sigtsmæssigt på behandlingen, styrker selvfølelsen, fordi det viser, at kroppen kan sammen med teknologien og dermed genererer en næsten alternativ frugtbarhed.

Omvendt giver lægens eller laborantens beskrivelse og vurdering af for eksempel en dårlig sædkvalitet ridser i selvfølelsen og får mange mænd til at føle sig "ikke-mandige" (Tjørnhøj-Thomsen 1999b). For de mænd, der $\mathrm{i}$ årevis har læst og lært historien om sædcellernes nødvendige mangfoldighed, hastighed og konkurrencementalitet (et gennemgående tema også i børnebøgerne), er beskeden om langsomme eller deforme sædceller svær at leve med.

Den intense visualisering, der er forbundet med fertilitetsbehandlingen, bidrager endvidere til en tidlig visuelt medieret forbundethed til de befrugtede $x g$ og spæde embryoner: "Da jeg så mine to æg, tænkte jeg, at der er mine to tvillinger," som en kvinde formulerede det. Denne tidlige forbundethed forstærker imidlertid også skuffelsen, når ægget ikke sætter sig fast i livmoderen og etablerer graviditeten: "Det var ikke bare et $x g$, der ikke havde sat sig fast, det var en abort", som en anden kvinde udtrykte dette tab.

Et tredje eksempel på overskridelse og forskydning vedrører forholdet mellem det naturlige og det kunstige. Naturen er nemlig på forunderlig og flertydig vis til stede i de anderledes tilblivelseshistorier. Både de barnløse og lægerne taler om, at teknologien giver "naturen en hjælpende hånd", ligesom nogle vender sig mod termen "kunstig befrugtning" og advokerer for termen "assisteret befrugtning". I klinikkens rum kan lægen for eksempel sige, at han "elsker at pille ved naturen", mens han senere på det trin i behandlingsforløbet, hvor det befrugtede $x g$ er lagt tilbage i kroppen, siger, at "nu er det op til naturen", eller nu er det "ren biologi". At sige, at behandlingsresultatet er op til naturen, sker også for at fritage parret for ansvar og skyldfølelse, hvis behandlingen ikke virker, fortalte personalet 
mig. Naturen - og det naturlige - gradbøjes til at legitimere visse tekniske procedurer frem for andre ved at erklære dem "så tæt på naturen som muligt". Endelig kan de barnløse i stilhed frygte, at naturen straffer dem med et handicappet barn eller et monstrøst væsen. Naturen indtager således alt efter kontekst og situation en mangetydig og multivalent position i de anderledes tilblivelseshistorier. I nogle versioner som et objekt, der ikke er helt perfekt, og derfor værdigt trængende til teknologisk assistance. I andre versioner som en magtfuld og gådefuld agent, skaber og dommer.

\section{Disciplinering}

Endelig bevirker fertilitetsbehandlingen forskellige former for disciplinering og objektivering af menneskers kroppe og liv. Fertilitetsbehandlingen retter sig primært mod kontrol af kvindekroppens hormonale system. Disciplineringen af kvindekroppen, der fordrer gentagne undersøgelser på klinikken, afføder også disciplinering af parrets hverdagsliv. En del af det store reproduktive arbejde (jf. Franklin 1997), der er forbundet med at være i behandling, er netop denne nødvendige koordinering af klinikkens tid, behandlingens tid, kroppens tid (cyklus) og arbejdstiden.

De fleste vil forsøge at gøre noget selv som en reaktion mod dette gennemkontrollerede forløb. Mange iværksætter raffinerede "selvteknologier" (Foucault 1988), som er ting, de skal eller ikke må gøre: At spise økologisk, ikke drikke kaffe, gå i alternativ behandling, bestille urtemedicin fra en klog kone i Jylland. Denne selvdisciplinering praktiseres i særlig grad af kvinder, hvilket hænger sammen med, at det er i deres krop, behandlingen skal lykkes. Det er også ofte kvinderne, der tager initiativ til at købe sædkvalitetsforbedrende kost- og vitamintilskud til deres partner. Selvdisciplineringen hænger også sammen med, at der ikke altid er forklaringer på, hvorfor teknologien ikke lykkes. Det er netop, når videnskaben ikke formår at give forklaringer, at der åbnes op for det magiske arbejde, der består i en mangfoldighed af private handlinger og besværgelser. Selv om nogle derved søger at genvinde en slags kontrol og holde afmagten fra døren, kan denne intense selvopmærksomhed også være slidsom og stressfremkaldende. ${ }^{6}$

\section{GRAVIDE BARNLØSE}

Dette afsnit belyser, hvordan erfaringer forbundet med at være barnløs og i fertilitetsbehandling sætter sig spor i tanker og erfaringer knyttet til graviditet og fødsel. 7 Når de barnløse bliver gravide efter barnløshed og fertilitetsbehandling, har de ofte gennemgået et længere følelsesmæssigt, kropsligt og socialt belastende forløb præget af medicinsk og teknologisk intervention, overvågning og usikkerhed. For mange barnløse bliver graviditeten en periode fyldt med bekymring, intens kropsopmærksomhed og tanker om det anderledes. Mange "tør ikke juble" over graviditeten og føle den graviditetsglæde, som de netop havde glædet sig til opleve og ikke mindst formidle til familie og venner. De lever i større eller mindre grad videre i et spændingsfelt mellem det normale og det naturlige på den ene side og det kunstige og anderledes på den anden (Tjørnhøj-Thomsen 1999a, 234).

Overgangen fra et kontrolleret og overvåget behandlingsforløb til et normalt graviditetsforløb er vanskelig at håndtere. Som en kvinde sagde: "Man render der på klinikken og ser folk med få intervaller, og når du så er blevet gravid, så ser du ikke nogen i flere måneder." Hun henviser til den tid, der går, fra kvinderne har forladt klinikken til de første læge- og jordemoderbesøg, og hun føler, at det var et "anti-klimaks at skulle skannes på det lokale hospital og være ganske almindelig gravid". Den medicinske teknologi yder kvinderne en særlig opmærksomhed, en slags omsorg, som kan være svær at lægge bag sig og undvære i en situation, hvor mange er bange for, at det skal gå galt. 
Kvinderne søger intenst efter kroppens tegn på graviditeten, men kroppens tegn er på grund af teknologiens indgriben usikre og svære at tolke og dermed også komplicerede at formidle til partneren, som også er spændt og bekymret. Usikkerheden betyder, at mange kvinder har stærke ønsker om ekstra klinikbesøg og ultralydsskanninger for at få bekræftet, at barnet lever. De barnløse kvinder har tillige hørt om og glædet sig til de tegn, som kroppen normalt giver ved graviditet: Brystspændning, kvalme og vægtforøgelse. De leder bestandigt efter og fortolker tilstedeværelsen eller fraværet af disse tegn som gode eller dårlige varsler. En kvinde fortalte, at hun havde haft "halsbrand og brystspænding, men $i k$ ke kvalme", som så mange andre kunne berette om. Fraværet af kvalme, syntes hun, var et “dårligt tegn". Der hersker en udbredt forestilling om, at kvalme er et tegn på graviditetens stabilitet.

Mange barnløse give udtryk for at føle sig anderledes gravide. ${ }^{8}$ Anderledesheden accentueres for eksempel i mødet med andre almindeligt gravide i fødselsforberedelsesgrupper. En kvinde sagde: "Vi tænker mere på babyen - og mindre på den gravide krop. De andre er fikseret på deres gravide krop." Denne bemærkning må fortolkes med reference til, at barnet meget tidligt i tilblivelsen gennem den intense visualisering er blevet konstrueret som en af kvindekroppen uafhængig "person". Kvindens krop er i centrum for fertilitetsbehandlingen, men den træeder i baggrunden $\mathrm{i}$ forhold til det perfekte $x g$ og det levende foster (Sandelowski 1994, Taylor 1998). Bemærkningen kan også forstås i forhold til kvindernes tidligere erfaringer som barnløse, hvor de, når de mødte gravide kvinder i det offentlige rum, periodevis blev grebet af følelser som vrede, misundelse og irritation over de gravides kropseksponering og "møven sig frem". Sådan, siger nogle, ønsker de ikke selv at gøre.

Anderledesheden manifesterer sig også i tanker om et anderledes barn. Det er tan- ker, der sjældent italesættes, men angsten for at få et monstrøst barn trænger sig på ind i mellem: En kvinde fortalte, at hun havde tænkt: "Har det seks arme, har det seks ben," men så havde hun forsøgt at overbevise sig selv om, at alt var, som det skulle være: "Alt efter befrugtningen, er det jo foregået som en almindelig graviditet."

I kvindernes fødselsfortællinger trænger det anderledes sig også på, og samtidig tyder meget på, at fødslen bliver en vigtigt begivenhed i almindeliggørelsen af graviditeten. Nogle kvinder registrerede, at jordemødre og fødselshjælpere talte om "kostbare børn" - med reference til barnets omstændelige tilblivelseshistorie, og de havde en fornemmelse af, at de derfor blev behandlet anderledes.

En kvinde fortalte, at hun havde haft en fantastisk fødsel, hun følte, hun havde styr på det, og hun kunne afslutte sin fødselsberetning med at sige, at det kunne godt være, hun ikke selv kunne lave børn, "men føde, det kunne jeg". En anden kvinde havde en dramatisk fødsel med kejsersnit og andre former for fødselsteknologi. Hun fortalte siden, at hun havde tænkt, at denne voldsomme fødsel nok skyldtes, at det slet ikke havde været naturens mening, at hun skulle have børn. Denne traumatiske fødsel blev således fortolket som naturens hævn over at være blevet krænket af teknologien.

Uanset kvindernes ønsker om at være almindelige gravide sætter erfaringerne som ufrivilligt barnløse og oplevelserne i forbindelse med behandlingen sig igennem i graviditetsperioden, som er fyldt med bekymringer, kropsopmærksomhed og tanker om det anderledes.

\section{AT FORTÆLLE EN ANDERLEDES TILBLIVELSESHISTORIE}

Denne artikel har vist, hvordan tilblivelsen og fortællinger om den bliver anderledes, når medicinsk teknologi bliver en del af den. Infertiliteten og teknologien skaber på flere måder uorden i menneskers kroppe og 
liv. Uordener, som kan være svære at leve med. Der findes ikke så meget viden om, hvordan ufrivillig barnløshed og medicinsk teknologi sætter sig spor. Men den historie, der skal fortælles, bliver anderledes. Jeg vil afslutte min artikel med at beskrive nogle af de tanker, der er forbundet med at skulle fortælle en anden historie:

Der var kvinder i min undersøgelse, der omhyggeligt havde forberedt at skulle fortælle deres barn om deres tilblivelse. En kvinde havde skrevet dagbog og klippet artikler ud for, som hun sagde, at hendes barn skulle få en forståelse for, "hvorfor vi har gjort det. Barnet skal have en slags afklaring så der kan komme en helhed," som hun sagde. "Ikke, fordi jeg tror barnet vil bære nag, men fordi barnet skal forstå, hvorfor jeg gjorde, som jeg gjorde. Men om 20 år er det sikkert noget andet"

Efter at hun havde født sit barn, vendte hun tilbage til dette emne og bogen, hun havde lavet.

"Før tænke jeg, at han skulle have den (altså bogen) før 20erne. Men det skal han ikke nu. Det skal ikke være sådan noget, jeg knalder ud til hans konfirmation, og hvor han er i puberteten og helt forvirret. Det har jeg gået og tænkt meget over. Ikke sådan, at jeg vil fortælle ham det, når han er 35 , at han er et reagensglasbarn. Men det er også svært at finde ud af, hvornår...Men så håber jeg, at vi kan finde ud af at få fortalt ham, at han er en ok dreng, og at han ikke skal føle sig anderledes."

Det er tanker om det anderledes, der er på spil i denne beretning. Kvinden har et behov for at forklare sig og finder, at dette er en historie, der skal fortælles af hensyn til barnets identitet og selvfølelse og af hensyn til hendes relation til barnet. Hendes problem er at sikre, at sønnen ikke kommer til at føle sig anderledes til trods for hans anderledes tilblivelseshistorie.

Hun må imidlertid leve med den usikkerhed, der altid er forbundet med at fortælle, nemlig at fortællingen fuldstændig- gøres hos den, der lytter (Ricoeur 1991, 21). Problemet er måske ikke så stort om 20 år, forestiller hun sig og sætter i nogen grad sin lid til, at det, der er anderledes og svært at fortælle nu, bliver mere naturligt og socialt anerkendt om 20 år, underforstået at teknologien med tiden føjes til og forandrer kollektive fortællinger og derfor vil gøre det lettere at fortælle og mindre problematisk at lytte. Måske er det derfor, at den alder, hun forestiller sig, sønnen skal have, når han skal høre og læse om sin tilblivelse, øges gradvist mens hun selv fortæller.

\section{Noter}

1. Forplantningsteknologi dækker over en kompleks koordinering af teknisk apparatur, procedurer, medikamenter, viden, erfaring, forskellige eksperter og interessenter, politiske aktører og medicinalfirmaer, der sammen har til hensigt at kurere eller omgå forskellige former for infertilitet. De teknikker, der normalt kendes under begrebet "kunstig" eller "assisteret befrugtning", er indeholdt i dette begreb. Insemination er en relativ simpel procedure, hvor sæden lægges ind i skeden, livmoderhalsen eller livmoderen med en tyndt kateder. Teknikker som reagensglasbefrugtning (IVF) og mikroinsemination (ICSI) fordrer, at kvinden behandles med forskellige hormoner, så hun til sidst producerer flere modne $æ$ g. Eggene tages ud af æggestokkene med en kanyle og befrugtes senere i laboratoriet ved, at sæden tilsættes xggene. Ved mikroinsemination, der anvendes, når manden har en meget dårlig sædkvalitet, sker befrugtningen ved, at laboranten med en nål placerer en udvalgt sædcelle inde i ægget. To døgn efter befrugtningen lægges de befrugtede $x g$ tilbage i kroppen, og 14 dage efter tages en blodprøve, som viser om kvinden er blevet gravid.

2. Den metodiske strategi var et antropologisk feltarbejde, hvor jeg fra 1995-1997 fulgte tre lokale grupper i Landsforeningen for Ufrivilligt Barnløse i Danmark. Deltagerobservation i disse grupper blev suppleret med dybdegående interviews af 22 par og med deltagerobservation på fertilitetsklinikker, medicinske konferencer, adoptionskurser m.m. Nogle af de par, jeg lærte at kende under mit feltarbejde, fik deres eget barn efter år i behandling, andre valgte at bruge donor. Nogle besluttede at 
adoptere, efter at behandlingen flere gange var slået fejl, og enkelte var nødt til at indstille sig på et liv uden børn.

3. Min undersøgelse medtager kun heteroseksuelle par.

4. Der er meget få xg til donation, så adgangen til denne behandlingsform er meget begrænset.

5. Personalet må derfor mindske ubehaget ved denne forskydning mellem det intime og det offentlige ved at etablere en slags privathed i det kliniske rum. For eksempel ved at låse døren til undersøgelseslokalet og trække gardiner og forhæng for (jf. Cussins 1998).

6. Nogle forskere peger på, at stress kan påvirke behandlingen $\mathrm{i}$ en negativ retning (Boivan and Takefman 1996).

7. Faglitteraturen giver ikke mange bud på, hvad det betyder at blive gravid og blive forældre efter en længere periode med fertilitetsbehandling (Sandelowski 1993, Schmidt 2000). Min viden er baseret på de par i min undersøgelse, som blev gravide, og det er primært kvinderne, der er i fokus her.

Min undersøgelse kan ikke sige noget om, hvordan barnløshed og fertilitetsbehandling sætter sig spor på længere sigt i forældreskab og familieliv.

8. Min undersøgelse giver ikke belæg for at sige, at de barnløse gravide kvinder er væsensforskellige fra andre gravide, for jeg har ikke foretaget en systematisk komparation. Men nogle af de kvinder, der forlader fertilitetsklinikken gravide, tilkendegiver selv, at de føler sig anderledes gravide, og det er denne følelse af anderledeshed, der er mit udgangspunkt her.

\section{LITTERATUR}

- Bech-Jessen, Anders (1987): En lille. Gyldendal, København.

- Bouquet, Mary (1993): Reclaiming English Kinship. Portuguese Refractions of British Kinship Theo$r y$. Manchester University Press, Manchester. - Carsten, Janet (1997): The Heat of the Hearth. The Process of Kinship In a Malay Fishing Community. Clarendon Press, Oxford.

- Cussins, Charis (1998): "Producing Reproduction: Techniques of Normalization and Naturalization in Infertility Clinics", in Sarah Franklin and Helena. Ragoné (eds.): Reproducing Reproduction. Kinship Power and Technological Innovation. University of Pennsylvania Press, Philadelphia.

- Delaney, Carol (1991): The Seed and the Soil. Gender and Cosmology in Turkish Village Society. University of California Press, Berkely.
- Boivan, Jacky and Takefman, Janet E (1996):

"Impact of the in-vitro fertilization process on emotional, physical and relational variables", in Human Reproduction vol.11 (4): 903-7.

- Fagerström, Grethe og Hansson Gunilla (1993):

Per, Ida \& Minimum. En bog om at vere sammen.

P. Haase \& Søns Forlag, København.

. Franklin, Sarah (1992): "Making Sense of Missed Conceptions: Anthropological Perspectives of Unexplained Infertility", in Meg Stacey (ed.): Changing Human Reproduction. Social Science Perspectives. SAGE Publications, London.

. Franklin, Sarah (1995): "Postmodern Procreation. A Cultural Account of Assisted Reproduction”, in Faye D. Ginsburg and Rayna Rapp (eds.) (1995): Conceiving the New World Order. The Global Politics of Reproduction. University Of California Press, Berkeley.

- Franklin, Sarah (1997): Embodied Progress. A Cultural Account of Assisted Conception. Routledge, London.

- Foucault, Michel (1988): Technologies of the Self. A Seminar with Foucault edited by Luther $\mathrm{H}$.

Martin, Huch Gutman and Patrick Hutton, Tavistock Publications, London.

- Hastrup, Kirsten (1992): Det antropologiske projekt. Om forbløffelse. Gyldendal, København.

- Kaaberbøl, Lene og Dyhre-Poulsen Susanne (1993): Den nat Kristian blev til. Klematis, Århus. - Martin, Emily (1991): “The Egg and the Sperm: How Science Has Constructed a Romance Based on Stereotypical Male-Female Roles", in Signs, vol. 16 , no. 3:485-501.

- Mayle, Peter (1975): "Hvor kommer jeg fra?” Den Sande forklaring uden dikkedarer og med tegninger. Lademan, København.

- Ricoeur, Paul (1991): "Life in Quest of Narrative", in David Wood (ed.): On Paul Ricoeur. Narratige and Interpretation. Routledge, London. - Sandelowski, Margarete (1993): With Child in Mind. Studies of the Personal Encounter with Infertility. University of Pennsylvania Press, Philadelphia.

- Sandelowski, Margarete (1994): "Separate but Less Unegual: Fetal Ultrasonography and the Transformation of Expectant Mother/Fatherhood", in Gender o Society, vol. 8 (2):230-45. - Schmidt, Lone (2000): "Fødsler og Barnløshed", in Karin Helweg-Larsen, Beth Lilja Pedersen og Anne Tønnes Pedersen (red.): Kvinder-køn, krop og kultur. Gyldendal, København.

- Strathern, Marilyn (1992a): After Nature: English Kinship in the Late Twentieth Century. Cambridge University Press, Cambridge.

- Strathern, Marilyn (1992b): Reproducing the 
future. Anthropology, Kinship and the New Reproduc-tive Technologies. Manchester University Press, Manchester.

- Strathern, Marilyn (1995): "Displacing Knowledge: Technology and the Consequences for Kinship", in Faye D. Ginsburg and Rayna Rapp (eds.) (1995): Conceiving the New World Order. The Global Politics of Reproduction. University Of California Press, Berkeley.

. Taylor, Janelle S. (1998): "Image and Contradiction: Obstetrical Ultrasound in American Culture", in Sarah Franklin and Helena Ragoné (eds.): Reproducing Reproduction. Kinship Power and Technological Innovation. University of Pennsylvania Press, Philadelphia.

- Tjørnhøj-Thomsen, Tine (1999a): Tilblivelseshistorie. Barnløshed, Slagtskab og Forplantningsteknologi i Danmark. Phd-rækken nr. 12, Institut for Antropolgi, København.

. Tjørnhøj-Thomsen, Tine (1999b):" “Det føles ikke mandigt på en måde". Mrnd og infertilitet”, in Kvinder, Køn éForskning, vol. 8 (3):71-89.

- Yanagisako, Sylvia og Delaney, Carol (eds.) (1995): Naturalizing Power. Essays In Feminist Cultural Analysis. Routledge, London.
SUMMARY

Most men and women take for granted that they will be able to have children, when they decide to have them. Some will not succeed, however, and take the chance of having children by technological intervention. Thereby they also change the standard version of $\mathrm{co}^{-}$ ming-into-being and the order it constitutes in radical ways. The article discusses what happens when the story parents normally tell their children about their coming-into-being is disordered and challenged by infertility and procreative technology, and what it means to experience and tell an other story.

Tine Tjørnhøj-Thomsen, antropolog, ph.d. Adjunkt ved Institut for Antropologi Københavns Universitet 